\title{
A Sucessful Academic Upgrading Programme Follow-up Over Five Semesters
}

\author{
ARTHUR M. SULLIVAN and PAUL WILSON*
}

\begin{abstract}
This paper describes a programme which attempted to upgrade prospects of students entering Memorial University of Newfoundland Regional College in Corner Brook in September of 1976. The elements of the programme are described and results are presented which compare the academic performance of marginal students who participated in the programme with that of those marginal students who did not.

The students were followed up for over a further four academic semesters and their academic results were compared at the end of each semester. The results demonstrate that except for a brief drop at the end of the second semester, the results of the students who participated in the programme were clearly superior to that of those in the comparison groups for each of the other semesters. The factors associated with these differences and their implications for further academic upgrading programmes are discussed.
\end{abstract}

\section{RÉSUMÉ}

Cet article décrit un programme qui a comme but de revaloriser les perspectives d'avenir des étudiants admis à l'University Memorial de Newfoundland à Corner Brook en septembre 1976. Une comparaison du fonctionnement académique des étudiants marginaux qui ont participé à ce programme avec les étudiants qui n'ont pas participé est présentée.

Les étudiants ont été suivis pendant quatre semestres académiques et leurs résultats ont été comparés à la fin de chaque semestre. Les résultats démontrent, avec une seule exception d'une légère baisse à la fin du deuxième semestre, que ceux qui ont participé au programme avaient un fonctionnement académique supérieur à ceux des autres groupes de l'échantillonnage. Les facteurs associés à ces différences et les implications pour d'autres programmes similaires sont discutés.

* Memorial University of Newfoundland 


\section{INTRODUCTION}

During the past twenty years, and coincidental with the adoption of 'open door' policies in most American and Canadian universities, courses and programmes attempting to remedy academic deficiencies of incoming students have proliferated (Hayward 1971, Entwisle 1960, Blake 1955). These courses, with their emphasis on counselling and study skills, reflect the finding that marginal academic performance is in part a function of poor study habits, poor preparation, and a variety of emotional and personality factors. (See Robyak, 1977, Van Zoost and Jackson 1974, Osterhouse 1972, Hayward 1971, Bednar and Weinberg 1970, Light and Alexakos 1970, Chestnut 1965, Entwisle 1960, Blake 1955, and Tresselt 1952).

It has, however, been noted that there is a lack of research in the area of college level academic support courses and especially a scarcity of studies that report extensive outcome data (Berg and Rentel 1966, Pauk) 1965, DiLorenzo 1964, Entwisle 1960, Blake 1955).

Further, it has been noted that while several studies report statistically significant gains in academic achievement, the educational significance of these gains has not usually been demonstrated (Pauk 1965, Entwisle 1960). Many reports do not include data on academic performance but rely upon surveys of study habits or instructors' comments as methods of evaluation.

The offering of academic support courses is now extensive, with traditional and nontraditional formats being employed, and with varying degrees of success being reported. However, these programmes have been of relatively short duration and have been offered in addition to but largely separated from the mainstream of the academic programme. In some universities, however, the effort has been more intense and it has involved major programmes, which have included several departments and administrative structures. These major programmes, especially the most successful have been documented in a recent publication, Overcoming Learning Problems by Roueche and Snow, (1977).

The authors describe twelve programmes which are intended to be exemplary, in that each has developed courses, programmes and special services, and an emphasis on the development of a more positive self concept. They note, however, "interestingly, even those paragon colleges who supplied additional supplemental information were unable to answer questions about student completion rates. The lack of response to our questions relating to student completion was essentially similar to that of our overall sample.

That is, more than half of the colleges were unable to supply follow-up information on their students."

In Canada, as a whole, there has been relatively little interest in remedial or up-grading programmes at the university level, apart from sporadic and isolated attempts in specific universities and especially community colleges, (see Hayward 1971). However, at Memorial University of Newfoundland for approximately fifteen years we have participated in attempts to upgrade the academic performance of incoming students. We have obtained follow-up data on the most recent and successful of our $\epsilon$ fforts.

\section{GENERAL BACKGROUND}

Various features of the Newfoundland geographic situation and educational structure 
make it particularly appropriate for innovations and research in the area of academic upgrading.

The province of Newfoundland, which includes the island and the mainland portion of Labrador, is large, with a small and sparse population. The area of Newfoundland is 140,000 sq. miles, i.e., approximately equal to that of the thirteen original American States, but the population is not quite 600,000 . Nearly half of its people are located in small and relatively isolated coastal settlements, spread along 1200 miles of coast.

The education system in Newfoundland consists of Kindergarten plus eleven years of elementary and secondary schooling. The final grade in the high school is grade eleven or junior matriculation. For those who wish to pursue university studies, this is followed by a four year general undergraduate degree programme. In comparison with most other parts of North America, it takes one year less to acquire an undergraduate degree in Newfoundland.

The facilities available in the high schools of the Province vary considerably from school to school. In the larger regional high schools of the urban centres, academic programmes include all of the sciences and all of the languages, and are essentially similar to those in the large urban areas in North America. In the smaller schools, i.e., the central and regional high schools outside of the urban areas, the academic programmes are severely limited. Many of the schools do not offer a course in Chemistry or Physics because adequate laboratory facilities and adequately qualified teachers are not readily available. Some students are, therefore, deprived in high school of an opportunity to acquire the academic background necessary for university study in many science and professional programmes.

\section{DEVELOPMENTS AT MEMORIAL UNIVERSITY}

Memorial University of Newfoundland was established as a university in 1949, although a two-year junior college had existed since the mid twenties. In 1949, enrollment was approximately 300 students, all enrolled in undergraduate programmes. Over the next fifteen years, enrollment increased dramatically and the number of programmes proliferated. By 1965, the university had almost 4,000 full-time students, and graduate programmes were offered in almost all subject areas. Furthermore, professional schools in engineering, medicine, social work, etc., had been, or were about to be established.

In the early 1960's, the University Senate became concerned about the high proportion of incoming students who failed during the first year, and who did not complete their programme of studies during the normal period of time. A report to the Senate, (Sullivan 1966) pointed out that within the faculty of Arts and Science, seventy percent of students failed one or more courses during the first year, and less than thirty percent completed the programme during the normal number of semesters.

Furthermore, it was found that success at university was correlated remarkably highly with prior academic achievement. Those students who had done well in Grade Eleven public examinations continued to do well in university, while those students who had a low academic average in Grade Eleven had virtually no chance of completing their programme within the required period of time, or indeed, at all. See Table I. 


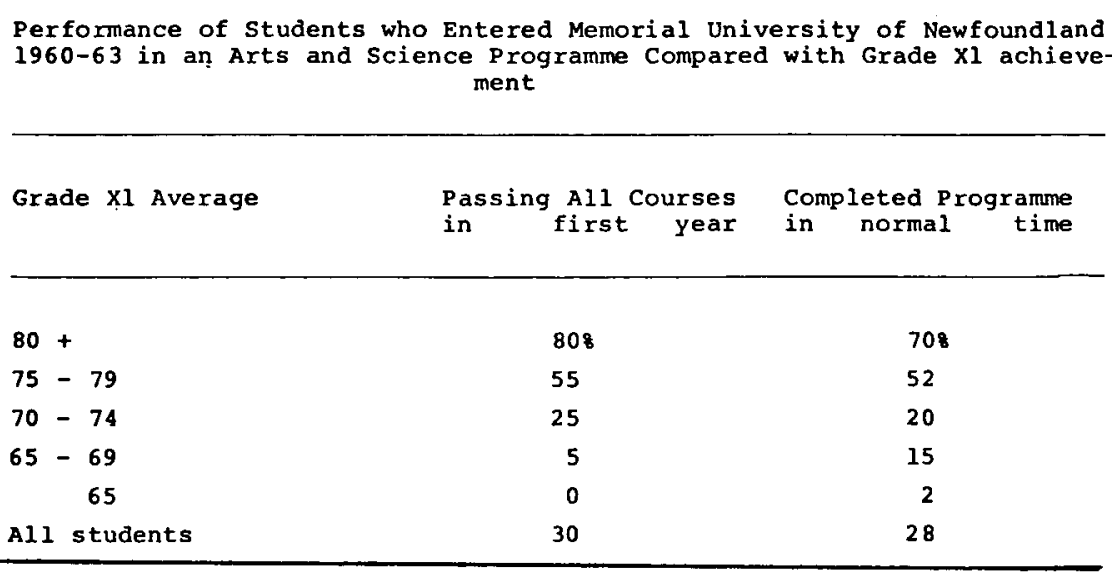

To increase the prospects of academic success for incoming marginal students the Senate, in 1967, agreed to two innovations within the University. These innovations were introduced in 1968, and are as follows:

(1) One semester academic upgrading foundation course in English, Mathematics, the Sciences and Languages. These courses were intended to upgrade the academic level of students who had either not taken the particular courses in Grade Eleven; or who had not attained a high mark in the relevant courses.

(2) A Junior Division was established to assume administrative responsibility for the foundation programme and for all first year courses. The Junior Division provided an advisory system whereby faculty members visited the high schools and counselled students on the appropriate academic programmes before entering university. The Division also provided counselling and academic and vocational guidance for all students during the first year.

There were three particular features associated with the Junior Division.

(i) Experienced teachers were appointed or selected to teach in the Division. Although all teachers had appropriate academic qualifications, (i.e., normally at least a Master's Degree), the basic criterion for appointment was demonstrated success in teaching.

(ii) All courses were taught in small sections. That is, in all subjects students were divided into groups of not more than forty, and normally about thirty, for teaching purposes. This ensured a very close contact between the students and faculty.

(iii) Each student was advised formally at least once, and sometimes twice, during the first semester through his or her faculty advisor concerning the progress which had been made during the term. Each student was advised, when appropriate, to take corrective measures, i.e., to plan and use his study time more effectively, to drop an academic course, or to enroll in a study skills course, etc. 
In 1973, the Senate established a committee to examine, evaluate and report on the operation of the Junior Division. The committee reported an increase in the achievement level of students - especially in the Arts and Science faculties, (i.e., an increase to $70 \%$ in the percentage of students passing all courses in the first year, and to nearly $40 \%$ in the percentage of students completing a programme during the normal number of semesters). It concluded that "these data indicate that there is an improvement in the students in the Arts and Science Faculties and in the professional schools. As the Junior Division was set up to improve the performance of students in this sub-set, it is concluded that the Junior Division has achieved its primary goal." (Sharpe, 1973).

The senior author was, at that time, Dean of Junior Studies. He pointed out (Sullivan, 1973) that those students who were weak in a particular subject or area, expecially in one of the sciences, and who needed that subject for the university programme selected, appeared to benefit considerably from the foundation courses offered. However he noted, "it seems that some students are generally weak, not only in specific academic skills, but also in general academic abilities. We would, therefore, like to introduce a general arts foundation programme which would emphasize reading and study habits, general problem solving, and the development of general academic abilities for those students who intend to enter the Arts or Education faculties."

The first real opportunity to develop and offer such a programme in a systematic and organized way came when Memorial University of Newfoundland opened its first regional college in Corner Brook in 1975. The senior author was named the first principal of the College. During the two years prior to the opening of the College, the designated college faculty visited the high schools in the area to be served by the College, and attempted to increase the interest in post-secondary education among the students in the high schools. They were remarkably successful in this, and when the College opened in 1975, the proportion of students from the area who continued their education to the university level was increased considerably from that in previous years.

TABLE II

\footnotetext{
Number of Students Enrolling in University from Western Newfoundland (College Area) and Central Newfoundland (Control Area) in 1973--1974 $1976--1977$
}

\begin{tabular}{|c|c|c|c|c|c|c|}
\hline \multirow[b]{2}{*}{$\begin{array}{l}\text { Academic } \\
\text { Year }\end{array}$} & \multicolumn{2}{|l|}{ Western } & \multicolumn{4}{|c|}{ Central } \\
\hline & University & College & Tota 1 & University & College & Total \\
\hline $1973-74$ & 252 & - & 252 & 237 & - & 237 \\
\hline $1974-75$ & 293 & - & 293 & 270 & - & 270 \\
\hline $1975-76$ & 155 & 325 & 480 & 237 & 27 & 264 \\
\hline $1976-77$ & 135 & 400 & 535 & 305 & 41 & 346 \\
\hline
\end{tabular}


Included among the new students attracted to the College was a high portion of marginal students who would not have attended the College had it not, by its proximity and active recruitment, encouraged them. It seemed that the College had a special obligation to these students. During the 1975-1976 academic year, the College attempted to meet this obligation by the provision of a special vocational counselling and study skills programme. The efforts were not as successful as had been hoped in that a high portion of marginal students did not complete the first year successfully.

It was decided therefore that the effort directed toward the academic upgrading of these students would be intensified in the following year.

\section{THE BASIC ACADEMIC SKILLS PROGRAMME}

In planning for the 1976-1977 academic year, the faculty of the college decided to attempt a major academic upgrading programme for those students who were considered to be in the marginal category, i.e., Grade Eleven averages of $65 \%$ or below admission by waiver of entrance requirements, or several years away from formal studies. The programme was planned for introduction in September of 1976.

The programme included a specially designed programme of courses in English, Mathematics, Psychology, History, French, Chemistry, and a Basic Academic Skills Course. A description of each of those courses is available from the senior author. It is sufficient to note at this time that:

(i) each of the courses involved additional periods for extra and remedial work, and that

(ii) special arrangements for the registration process were planned so that all the students in the programme could register in these special sections (i.e., cluster registrations).

The programme had several features which were important. These were:

1. The Basic Academic Skills course was counted as one of the courses which would make up the normal programme of the student, but no formal university credit was given for it. That is, each student in the programme could take four academic credit courses, together with the Basic Academic Skills course during the first semester. (It was intended that those students who continued would make up this dericiency by taking a course in summer school as an extra course, at some later time in their academic programme.

2. Marginal students would be advised of the programme, and would be encouraged to enroll in it, but no student would be required to do so.

3. The programme was to be given a high priority by the university administration and by all members of the facuity. All faculty members were made aware of the programme and all in the course of their normal advising, discussed the programme with students and recommended that those students who were within the marginal category should enroll for it.

4. The teachers in the programme were experienced and highly regarded teachers within the college. Virtually all of the teachers would have been judged as 'excellent' or 'outstanding' in their teaching abilities, and most were highly experienced within the educational system, both at the high 
91 A Successful Academic Upgrading Programme: Follow-up Over Five Semesters

school and university level. The teachers included two full professors, four associate professors and two assistant professors.

5. The programme was to be co-ordinated so that faculty members who taught in the programme could meet at least once a week to discuss the problems presented by the programme itself, and the progress of individual students.

6. All the faculty members in the programme agreed that the basic numeric and linguistic skills were to be emphasized in all courses. For example, the new vocabulary which was to be encountered in each subject, in each weekly unit, was passed on to the Basic Academic Skills teacher, and the English teacher, and covered in these courses as well as the academic course. The students lost marks for poor English, poor language use, and mistakes in calculation in all of the courses.

The intention of the programme was very clearly to increase the prospects of achieving academic success and of completing a university programme successfully. It was, therefore, agreed that the evaluation of the programme would be in terms of the subsequent student performance within the College or within the University system.

Three features of the programme were arbitrary, although perhaps important.

1. No attempt was made to administer formal pre-and post- tests of cognitive and academic skills, personality and study habits. This was partly because of the administrative difficulties in making the necessary arrangements and also because we did not want to focus too much emphasis upon the experimental nature of the programme. It is, however, a disadvantage from an experimental point of view.

2. Marginal students in all intended faculties were permitted to register for the programme. Thus science students were encouraged to take the programme and to register for the Chemistry and Mathematics courses.

3. The programme was to be terminated at the end of the first semester. This would force the students to seek help on their own during the second semester, if they wished to do so. (This decision may have been unfortunate for those who did not progress satisfactorily during the first semester but it was necessary from an investigative and administrative point of view.)

\section{RESULTS}

In September of 1976, it was determined that approximately 100 of the incoming students would fit into the marginal category. All of these were informed of the programme and advised to enroll in it. Approximately half (46), (49 students actually signed up for the programme but two dropped out of the programme, and one dropped out of the College during the early weeks of the semester) of the studerts did enroll in the programme. The remaining students opted to take a normal five-credit course load, but were encouraged to register for the regular study skills and to take advantage of the counselling services provided by the College.

The characteristics of those marginal students who opted to take the programme and those who did not are given in Table III.

This Table demonstrates that the two groups of students were alike in virtually all respects except that a higher proportion of rural students opted to take Basic Academic Skills (BAS) programme, and a lower proportion of Science students registered for the 


\begin{tabular}{lcc}
\hline & \multicolumn{2}{c}{ CHARACTERISTICS OF BAS AND COMPARISON GROUPS } \\
\cline { 2 - 3 } & \multicolumn{1}{c}{ BAS } & COMPARISON \\
& $N=46$ & $\mathrm{~N}=49$ \\
Grade XI Average & 62.48 & 62.88 \\
Arts/Education & 71.78 & 53.18 \\
Science & 28.38 & 46.98 \\
Urban & 27.38 & 58.78 \\
Rural & 72.78 & 41.38 \\
Males & 69.68 & 65.38 \\
& & \\
\hline
\end{tabular}

programme. We, therefore, decided to treat this group of students as a "Comparison group", although they were not in the true sense of the term a "control group". We have reason to believe that taking the programme was more random and arbitrary than would have been predicted. It appeared during later discussions with students that some advisors highly recommended the programme, while others had not. Students were not likely to select a programme which permitted the acquisition of only four university credits unless they were strongly encouraged to do so. Registration in the programme was therefore to a large degree influenced by the random and arbitrary assignment to a faculty advisor.

We also gathered data from the group of students who met the criteria for inclusion in the marginal category in 1975, the year before the programme was offered, and treated these as a second "comparison group". The results for the end of the first semester are presented in Table IV.

In this, and in subsequent Tables, the column labelled BAS refers to those students in 1976 who enrolled for the BAS programme. 1976 Comparison refers to those students who were offered the option of enrolling in the BAS programme but elected not to do so; and the 1975 Entrants refers to those students were marginal in 1975, before the programmed was offered.

TABLE IV

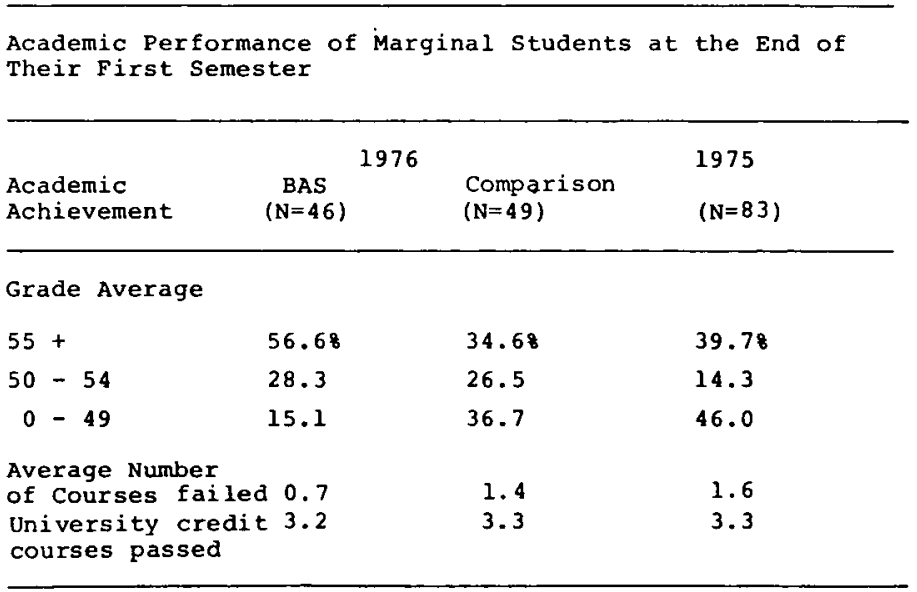


93 A Successful Academic Upgrading Programme: Follow-up Over Five Semesters

Table V shows that the academic performance of the BAS students was superior in virtually all respects to that of the conventional group. That is, the BAS students failed fewer courses, obtained higher marks, and generally had a more successful academic career during the first semester.

This relatively higher level of success, however, might be attributed to the fact that the BAS students were taking a programme of only four rather than five courses. However, when a comparison is made between the BAS students and those 1975 entering students who took only four courses, the performance of the BAS students is still clearly superior.

TABLE V

\begin{tabular}{|c|c|c|c|c|}
\hline \multirow[b]{2}{*}{$\begin{array}{l}\text { Number of } \\
\text { Courses Failed }\end{array}$} & \multicolumn{2}{|c|}{1976} & \multicolumn{2}{|r|}{1975} \\
\hline & $\begin{array}{c}\text { BAS } \\
(\mathrm{N}=46)\end{array}$ & $\begin{array}{r}\text { Other } \\
(\mathrm{N}=49)\end{array}$ & $\begin{array}{c}\text { Number } \\
\text { Five } \\
(\mathrm{N}=51)\end{array}$ & $\begin{array}{c}\text { of Courses Taken } \\
\text { Four } \\
(\mathrm{N}=15)\end{array}$ \\
\hline 0 & 43.58 & 28.68 & 32.88 & 26.78 \\
\hline 1 & 41.3 & 36.7 & 11.5 & 6.7 \\
\hline 2 & 8.3 & 14.3 & 26.2 & 26.7 \\
\hline 3 & 4.3 & 8.3 & 6.6 & 26.7 \\
\hline 4 & 2.2 & 10.2 & 4.9 & 13.3 \\
\hline 5 & - & 2.0 & 1.6 & - \\
\hline
\end{tabular}

When the groups were divided into those students who opted to register for a Science programme, i.e., took a laboratory Science, and those who did not, it was found that the programme was much more successful in the case of Arts students, i.e., those not taking a laboratory Science, than in the case of Science students.

TABLE VI

\begin{tabular}{|c|c|c|c|c|}
\hline \multirow[b]{2}{*}{$\begin{array}{l}\text { Grade } \\
\text { Average }\end{array}$} & \multirow[b]{2}{*}{$\begin{array}{l}\text { Not Taking A } \\
\text { Lab. Science } \\
(N=33)\end{array}$} & AS & OTHER & \multirow[b]{2}{*}{$\begin{array}{l}\text { Taking A } \\
\text { Lab. Science } \\
\quad(N=28)\end{array}$} \\
\hline & & $\begin{array}{l}\text { Taking } A \\
\text { Lab. Science } \\
\quad(N=13)\end{array}$ & $\begin{array}{l}\text { Not Taking A } \\
\text { Lab. Science } \\
\quad(N+26)\end{array}$ & \\
\hline $55+$ & 63.68 & 30.88 & 46.18 & 21.48 \\
\hline $50-54$ & 24.2 & 46.2 & 19.2 & 32.1 \\
\hline $0-49$ & 12.1 & 23.1 & 34.6 & 46.4 \\
\hline
\end{tabular}


The academic performance of the students was followed during the second semester. Table VII gives the performance of the BAS students in comparison with the ones who did not opt to take the programme.

TABLE VII

\begin{tabular}{lcc}
$\begin{array}{l}\text { Academic Performance of BAS and Others - Students After Two } \\
\text { Semesters of Study }\end{array}$ & $\begin{array}{c}\text { Bthers } \\
(\mathrm{N}=40)\end{array}$ \\
\hline $\begin{array}{l}\text { Academic } \\
\text { Performance }\end{array}$ & & \\
\hline Grade Average & 40.08 & 20.08 \\
$55+$ & 25.0 & 40.0 \\
$50-54$ & 35.0 & 40.0 \\
$0-49$ & 2.1 & 2.9 \\
$\begin{array}{l}\text { Cumulative Number } \\
\text { Of Courses Failed }\end{array}$ & & \\
\hline
\end{tabular}

During the second semester the academic superiority of the BAS group of students was no longer as evident - a higher proportion of students.continued to do well but a high proportion (similar to that in the comparison group) obtained an average of less than $50 \%$. Thus, some students who had had at least marginal success during the first semester did not continue this level of achievement into the second semester. In this context however, it must be recognized that the BAS students were taking a full university programme for the first time in their careers, and that they were doing so without any specially provided additional help.

We have now, in 1979 , been able to follow the progress of these students over a further three semesters, and we have complete data concerning the performance of all groups over the first five semesters of their university careers. Table VIII presents information concerning the performance over five semesters of the two groups of students identified above, i.e., the BAS students and the students who did not enter the programme, but were eligible to do so (the comparison group).

It can readily be seen that subsequent to the first academic year the performance of the BAS group of students is superior to that of the comparison on all measures, i.e., retention, average number of courses completed, number of courses failed, etc. The superior performance of the BAS vs. the comparison group is also demonstrated graphically in Figure 1 below which tabulates the proportion of students, of those eligible to return, who remained in clear standing at the end of each semester. It is evident that the performance of the BAS students reached a relatively high and stable level after the second semester. The performance of the comparison group is lower and continued to decline after each additional semester.

The retention rate among the 1976 groups is relatively low. However, this is to be expected since the group was clearly a high risk and marginal group, and without the intervention of the programme, it is safe to predict that only a small proportion of the students would have continued their university programme successfully. 
The Retention and Academic Performance of the BAS and Comparison Groups over

Five Semesters

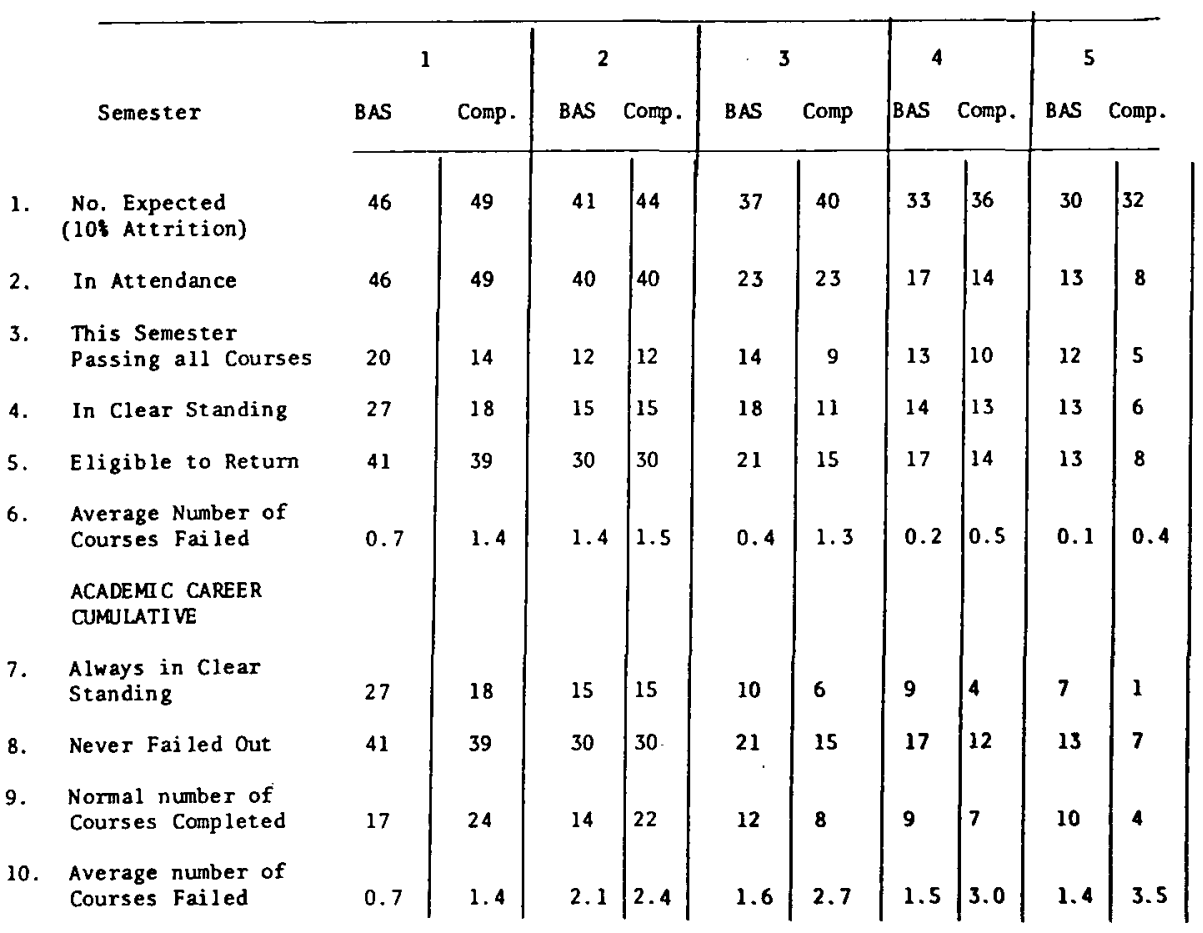

A certain number of students in each group who were eligible to return to university did not do so. These students either terminated or interrupted their academic careers, or transferred to another post-secondary institution. When this factor is considered, then after five semesters 29 (63\%) of the BAS were either in university, (13), or eligible to return (16), while $22(47 \%)$ of the comparison group were either in university (8), or eligible to return (14).

It seems clear, therefore, that those students who participated in the BAS programme did, in fact, have their prospects of a successful university career enhanced.

It might be argued that the superior performance of the BAS group may be attributed to the higher proportion of Arts students within that group. That is if the failure rate among science students is higher than among arts students then the difference between the groups may be associated primarily or entirely with the higher proportion of unsuccessful science students in the comparison group. We decided, therefore, to divide the group into separate sub-groups of arts and of science students and to examine the performance of each sub-group separately. The results are presented in Table IX (a) and (b). 
96 Arthur M. Sullivan

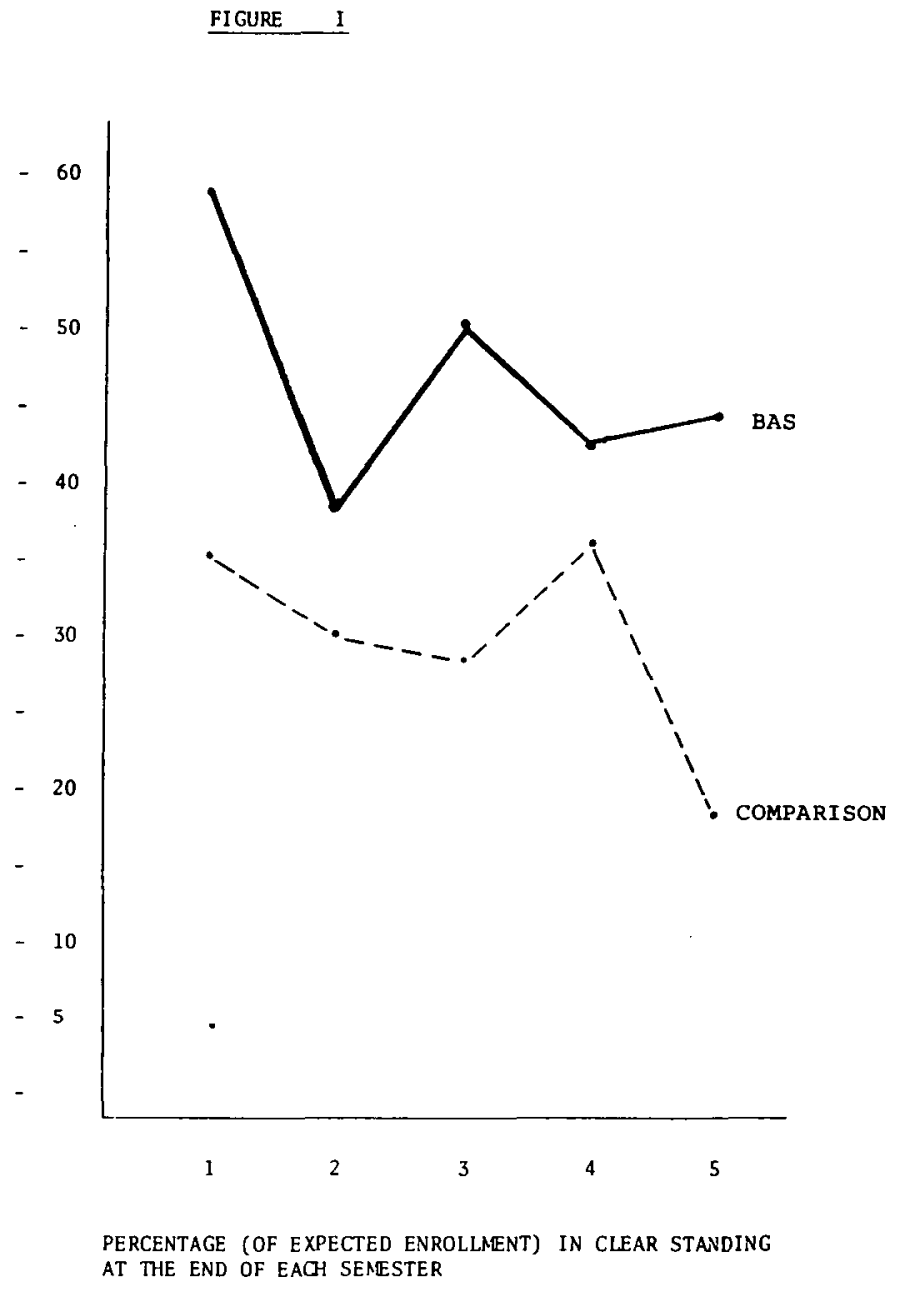

These results clearly demonstrate that when the performance of arts students only is examined the magnitude of the difficiencies between the two groups is enhanced. That is in all measures the superiority of Arts BAS students is clearly superior to that of comparison Arts students.

The programme, in fact, did not enchance the prospects of academic success for Science students. This finding suggests that the abilities and skills associated with success in an Arts programme are different from those associated with success in a Science programme. This proposition has been put forward by other researchers and writers (Snow 1965 and Hudson 1966). It is likely that a successful programme for upgrading the academic skills of marginal prospective Science students should include a much greater emphasis on numerical skills, problem solving and scientific thinking.

Is there any explanation for the superior performance of the BAS students in subsequent semesters, except the contribution made by the programme itself? Some might 
97 A Successful Academic Upgrading Programme: Follow-up Over Five Semesters

TABLE IX (a)

PERFORMANCE OF BAS AND COMPARISON ARTS STUDENTS

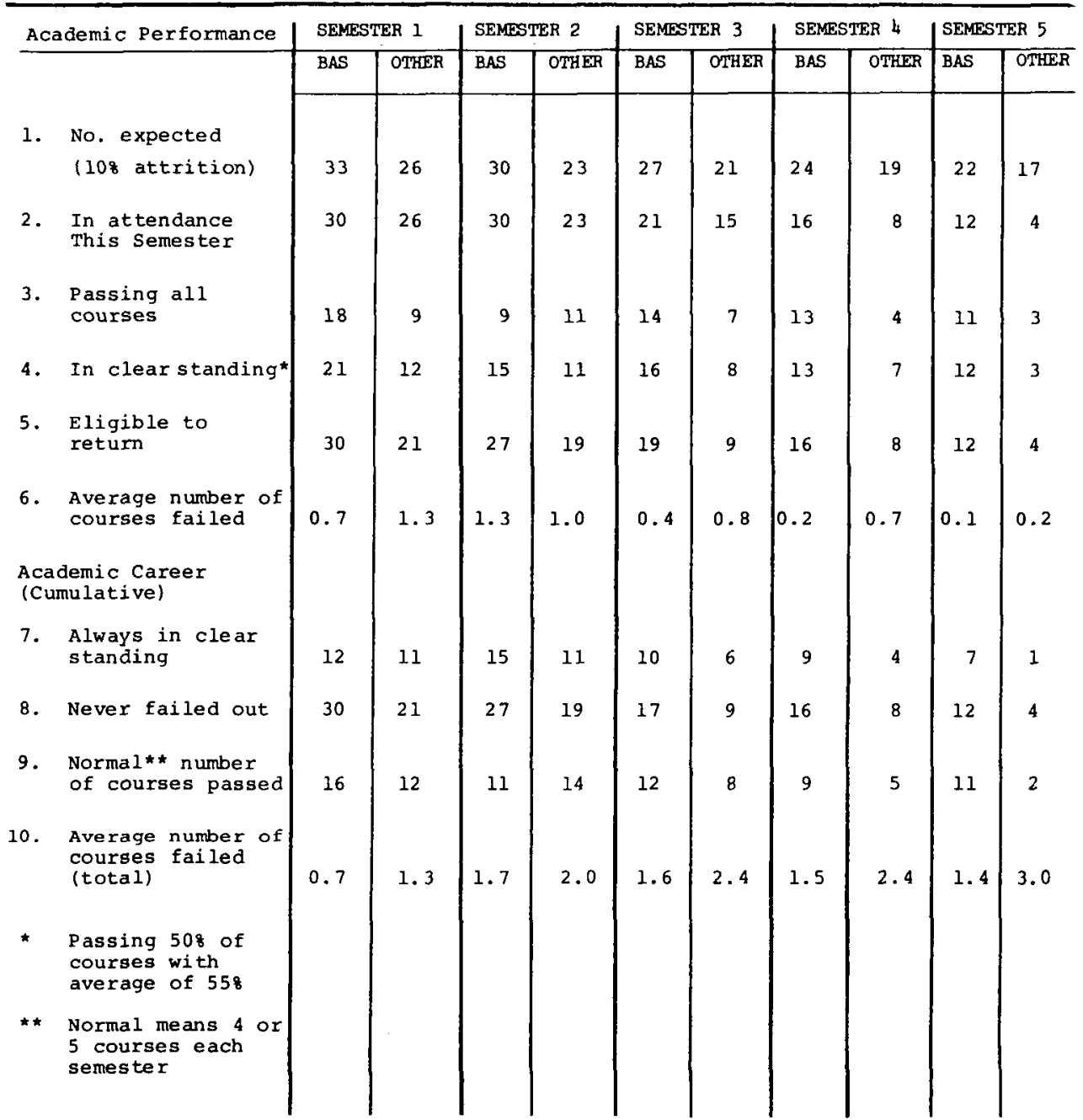

argue that the students who went into the programme were those most highly motivated and who had the strongest desire to complete their university programme successfully. That is, it might be possible to attribute the greater success of the BAS students to degree of motivation, rather than to the programme.

We have attempted to obtain data relevant to this suggrstion. Among the 1975 entrants in the marginal category, a small number (16) elected to register for the study skills course which was then being offered. This group would probably be more directly comparable with the 1975 students who elected to take the BAS course in that each group was suffi- 
TABLE IX (b)

PERFORMANCE OF BAS AND COMPARISON SCIENCE STUDENTS

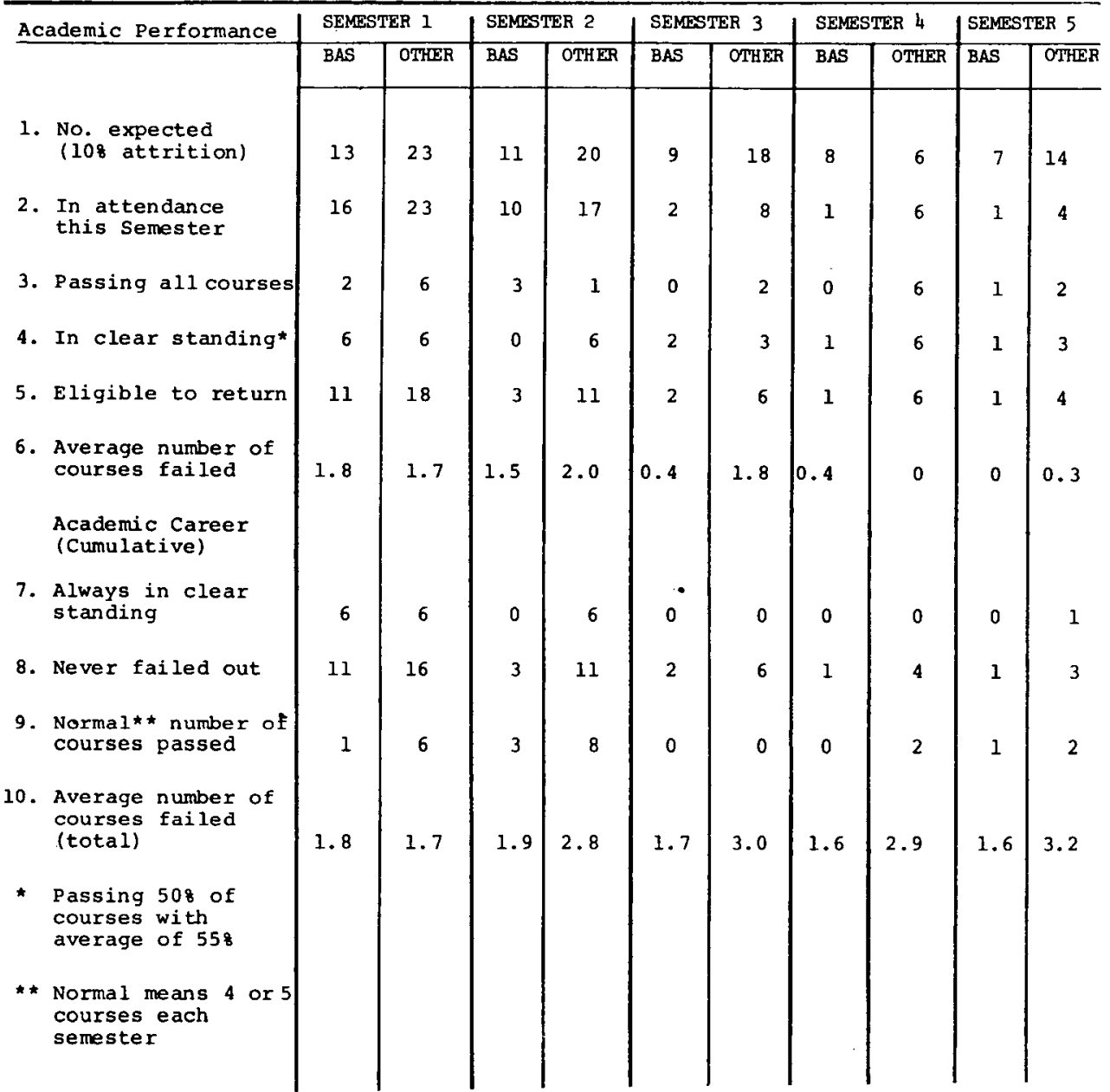

ciently motivated to seek additional help with study difficulties. The performance of these two groups over the five semesters is presented in Table X.

Table X shows that, after the second semester, in all measures, the performance of the 1976 BAS students is superior to that of the 1975 marginal students who elected to take the study skills course.

\section{DISCUSSION}

These results demonstrate that under certain circumstances (which include a high priority being placed by the learning institution and the participation of experienced and senior teachers in a co-ordinated programme), it is possible to produce an academic intervention 
99 A Successful Academic Upgrading Programme: Follow-up Over Five Semesters

TABLE X

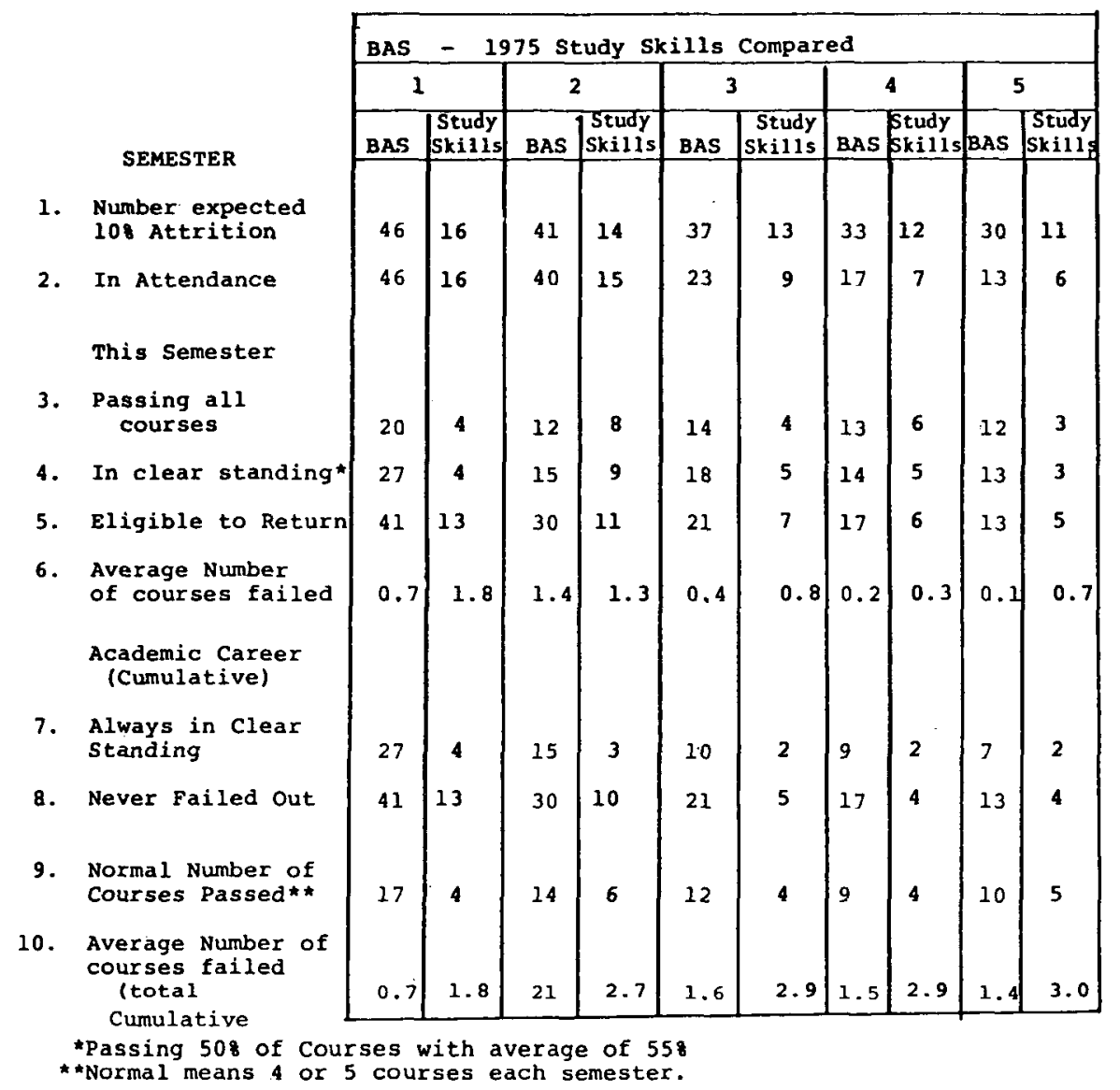

programme which is clearly successful in enhancing the future academic prospects of marginal students.

Interestingly, the features which we have determined to be associated with success are similar to those which have been identified by Roueche and Snow (1977) as being necessary for success. These are:

1. Teachers are the key;

2. Supportive services are vital for success;

3. Proper organizational support is essential for effective programmes;

4. A considerable amount of effort and time must be involved in the preparation and presentation of the programme.

The success of our programme should, therefore, offer encouragement to those who are embarking in programmes in the area of remedial education at the post-secondary level. The effort required in establishing a successful programme is enormous and this must be 
clearly recognized; but, when the effort and commitment are provided, clearcut and encouraging results are possible and can be demonstrated.

We are not in a position to say which specific changes in the students were most crucial in contributing to the success of the programme. We believe that an increase in academic skills and knowledge, especially vocabulary and language usage was a major factor. We also believe that feelings of esteem and improved self-image which resulted from the attention paid to the students by high prestige faculty members and from the positive experiences with early academic success were also of considerable importance. Further clarification of these factors would require an extensive pre- and post-treatment testing programme.

For our own planning at Memorial University, these changes are suggested for the future.

We have examined the results of all students and it is evident that those students who succeeded (i.e., obtained averages of $55 \%$ or higher) in the programme during the first semester continued to do well afterwards, but those students who did not succeed in the programme, (i.e., obtained marks of $54 \%$ or less), during the first semester, did not do well in subsequent semesters. It is likely that these students require further academic upgrading and would benefit from it.

The next time the programme is offered, therefore, a second semester will be included. Those students who do well at the end of the first semester will progress to a regular university programme. Those students who do not do well at the end of the first semester will continue into the second semester which will have the same characteristics as the first, i.e., reduced academic course load, a continuation of the basic academic skills course, and special sections or additional periods of remedial work in the regular course. It is likely that this additional effort will increase the proportion of students who will subsequently perform well academically.

It is highly likely that a small proportion of students will not do well at the end of the second semester. We feel however, that no further increase in the duration of the programme would be desirable. Students must be prepared to meet the challenges of the university programme on their own after a certain period of help. We believe that two semesters would be the maximum amount of time which should be allocated to a helping programme.

A second change that is necessary is the introduction of a special programme for Science students. We are in the process of planning a programme which is designed specifically to meet the needs of Science students. The programme will concentrate upon study skills, upon basic mathematical concepts, and upon the fundamentals of problem solving and the scientific orientation. A group of incoming marginal Science students will be offered this programme for one or two semesters, as outlined above.

The programme will be planned to last for one or two semesters as in the case of the arts programme. It will be offered to incoming marginal students on a voluntary basis similar to that described in this report as soon as it is possible to make the necessary academic and administrative arrangements.

r Finally, we plan to combine an extensive testing programme with the upgrading programme. Eligible students who elect to take the programme, and those who do not, will complete a battery of tests that will include academic aptitude and achievement tests, 
101 A Successful Academic Upgrading Programme: Follow-up Over Five Semesters

as well as interest and personality tests. These tests will be re-administered immediately after the conclusion of the programme and at a later time in the students' academic careers. In this way, it should be possible to determine what specific changes are brought about by the programme, the degree to which these changes persist and the changes which are most highly correlated with academic success.

\section{REFERENCES}

Bednar, B.L., and Weinberg, S. (1970) Ingredients of Successful Treatment Programs for Underachievers. Journal of Counselling Psychology.

Berg, P.C., and Rentel, E.M. (1966) Improving Study Skills. Journal of Reading.

Blake, W.S., Jr. (1955) The Effects of Structured and Unstructured Group Counselling on Male College Students. Journal of Counselling Psychology.

Dilorenzo, L.T. (1965) The Discriminating Effects of a College How to Study Course. Journal of Educational Research.

Entwisle, Doris R. (1960) Evaluations of Study Skills Courses: A Review. Journal of Educational Psychology.

Hayward, F.M. (1971) Reading and Study Instruction in Canadian Universities and Colleges. Journal of Reading.

Hudson, Liam., (1966) Contrary Imaginations: A Psychological Study of the Young Student, First Edition, New York, Schocken.

Light, L.L., and Alexakos, C.E., (1970) Effects of Individual and Group Counselling on Study Habits. Journal of Educational Research.

Osterhouse, R.A., (1972) Desensitization and Study Skills Training as Treatment of Two Types of Test-Anxious Students. Journal of Counselling Psychology.

Pauk, W., (1965) Study Skills and Scholastic Achievement - with comment by T. Clymer. Reading Teacher.

Roueche, John E., and Snow, Jerry J., (1977) Overcoming Learning Problems, First Edition, San Francisco, Jossey Bass, Inc.

Robyak, J.E., (1977) A Revised Study Skills Model: Do Some of Them Practice what We Teach? Personnel and Guidance Journal.

Sharpe, J.J., (1974) Data on Academic Achievement.

Snow, C.P., (1965) Two Cultures: A Second Look, Second Edition, Cambridge University Press.

Sullivan, A.M., (1966) Report of the Senate Committee on the Feasibility and Desirability of Junior Colleges in Newfoundland.

Sullivan, A.M., (1973) Report to the Senate Committee Evaluating the Work of the Junior Division -1968 to 1972. 